\title{
Pengaruh Faktor Kepribadian terhadap Toleransi Risiko Keputusan Investasi Saham
}

\author{
Putri, F. K., Bramanti, W. G., dan Hakim, M. S. \\ Jurusan Manajemen Bisnis, Fakultas Teknologi Industri, Institut Teknologi Sepuluh Nopember (ITS) \\ Jl. Arief Rahman Hakim, Surabaya 60111 Indonesia \\ e-mail:ms_hakim@mb.its.ac.id
}

\begin{abstract}
Abstrak-Saham merupakan salah satu instrumen investasi terpopuler yang tergolong dalam instrumen aset berisiko tinggi. Toleransi risiko menjadi salah satu faktor penting yang menjadi pertimbangan investor dalam menentukan preferensi investasinya pada saham. Toleransi risiko terdiri dari berbagai macam aspek, termasuk diantaranya adalah karakteristik kepribadian investor. Penelitian terdahulu membuktikan bahwa karakteristik kepribadian individu memiliki pengaruh terhadap pengeluaran, pengelolaan investasi, dan toleransi risiko. Penelitian ini bertujuan untuk membuktikan pengaruh karakteristik kepribadian terhadap toleransi risiko keputusan investasi saham. Penelitian ini menggunakan data primer yang berasal dari 83 sampel penelitian yang merupakan investor aset keuangan di Surabaya. Teknik analisis data yang digunakan dalam penelitian ini adalah analisis regresi linier. Hasil penelitian ini adalah bahwa karakteristik kepribadian tidak mempengaruhi toleransi risiko investor, namun toleransi risiko memiliki pengaruh terhadap keputusan investasi saham.
\end{abstract}

Kata Kunci-Behavioral Finance, Karakteristik Kepribadian, Keputusan Investasi Saham, Toleransi Risiko.

\section{PENDAHULUAN}

$I^{1}$ NDONESIA termasuk ke dalam salah satu negara dengan stabilitas ekonomi yang cukup baik, yang mana Indonesia tetap bisa mencatatkan kinerja ekonomi yang cukup baik walaupun sedang berada di tengah berbagai tantangan perekonomian global dan domestik, ekonomi Indonesia tetap bisa bertumbuh sebesar 4,79\% pada tahun 2015 [1]. Segala upaya pemberlakuan kebijakan dilakukan oleh Pemerintah melalui paket kebijakan ekonomi untuk mendorong pertumbuhan ekonomi Indonesia. Melalui kebijakan-kebijakan tersebut, Indonesia juga berusaha menciptakan iklim investasi yang kondusif. Namun, menariknya kondisi pasar modal Indonesia ini ternyata kurang dimanfaatkan oleh investor lokal untuk ikut andil dalam aktivitas pasar modal Indonesia. Hal ini dapat dilihat dari proporsi domestic investment yang selalu lebih kecil dibandingkan proporsi foreign investment dari tahun ke tahun. Dominasi pihak asing terhadap realisasi investasi di Indonesia ini tentunya akan merugikan Indonesia karena pasar modal Indonesia akan sangat terpengaruh oleh kondisi global [2].

Jenis investasi dibedakan menjadi 2, yaitu investasi aset riil dan aset keuangan. Investasi aset keuangan terdiri dari saham, obligasi, dan aset derivatif [3]. Kumpulan aset-aset keuangan tersebut biasa disebut dengan portofolio investasi. Dari beberapa jenis aset keuangan ini, saham merupakan salah satu instrumen yang paling dikenal di kalangan masyarakat sekaligus sebagai instrumen paling populer di kalangan investor, meskipun saham termasuk ke dalam aset yang berisiko tinggi. Ketertarikan investor pada instrumen saham ini berkaitan dengan peluang imbal hasil yang tak terbatas dari instrumen ini, yang mana hal ini tidak terdapat pada instrumen lainnya seperti obligasi dan instrumen perbankan. Dalam proses investasi, pembentukan portofolio investasi senantiasa diiringi dengan tahap keputusan investasi alokasi dan seleksi aset. Keputusan investasi investor individu sangat bergantung pada toleransi risiko masing-masing individu tersebut. Keputusan investasi individu berdasarkan teori keuangan tradisional sangat erat kaitannya dengan rational investor dan efisiensi pasar. Namun, sejak tahun 1980-an beberapa peneliti menemukan bahwa terdapat anomali terhadap hipotesis mengenai efisiensi pasar dalam teori keuangan tradisional karena adanya irrational investor yang bertindak berdasarkan emosi dan faktor psikologi [4].

Sebanyak $77 \%$ pengaruh perencanaan keuangan investor pribadi dipengaruhi oleh diri investor itu sendiri [5]. Pada penelitian sebelumnya [6][7], disebutkan bahwa terdapat kombinasi antara faktor demografi, karakteristik personal, pasar, dan faktor-faktor yang terkait lainnya pada diri investor yang mempengaruhi keputusan investasinya. Karakteristik kepribadian individu memiliki pengaruh terhadap pengeluaran, pengelolaan investasi dan toleransi risiko. Kepribadian extraversion, conscientiousness dan openness to experience akan cenderung memilih instrumen investasi dengan tingkat risiko yang tinggi, sementara kepribadian dengan karakter agreeableness dan neuroticism akan cenderung memilih instrumen investasi rendah risiko [8].

Penelitian ini bertujuan untuk mengetahui pengaruh kepribadian terhadap toleransi risiko keputusan investasi saham, sehingga penasehat investasi dapat memberikan rekomendasi portofolio investasi yang sesuai menurut kepribadian masing-masing investor.

\section{TINJAUAN PUSTAKA}

\section{Kepribadian}

Kepribadian merupakan cara individu untuk berinteraksi, bereaksi, dan bersikap dengan individu lain dan sering ditunjukkan melalui karaktertistik terukur [9]. Salah satu teori kepribadian yang popular adalah teori big five factor yang dipopulerkan oleh Goldberg. Sesuai dengan namanya, terdapat 5 faktor karakteristik kepribadian dalam model ini, diantaranya 
adalah openness to experience, conscientiousness, extraversion, agreeableness, dan neuroticism [10].

Openness $(\mathrm{O})$ adalah pribadi yang menyukai hal-hal baru. Individu ini memiliki sifat imajinatif, kreatif, dan berwawasan luas. Conscientiousness (C) adalah pribadi yang mencerminkan individu yang stabil dan tidak mudah terpengaruh. Individu dengan kepribadian ini sering digambarkan sebagai pribadi yang tekun, disiplin, dan teliti dalam pengambilan keputusannya. Extraversion (E) adalah pribadi yang berorientasi pada lingkungan eksternal. Pribadi dengan karakteristik ini digambarkan sebagai pribadi yang suka bergaul, tegas, dan memiliki jiwa kepemimpinan yang kuat. Agreeableness (A) merefleksikan individu yang hangat, lemahlembut, ramah, dan pemaaf. Sedangkan neuroticism (N) merefleksikan individu dengan ketidakstabilan emosional terkait dengan kecemasan yang tinggi dan sangat sensitif [11]. Risiko Investasi

Risiko investasi merupakan input yang harus diterima oleh investor untuk dapat menerima output investasi yang berupa imbal hasil [12]. Terdapat dua jenis risiko investasi, yaitu risiko sistematis dan risiko tidak sistematis. Risiko sistematis merupakan risiko yang erat kaitannya dengan pergerakan dan perubahan harga pasar suatu saham tertentu yang disebabkan oleh antisipasi investor terhadap imbal hasil yang diharapkan, sedangkan risiko tidak sistematis merupakan risiko yang bergantung pada spesifikasi masing-masing perusahaan. Risiko ini dapat dihilangkan melalui diversifikasi. Semakin tinggi fluktuasi tingkat imbal hasil yang diharapkan investor, maka akan semakin tinggi risiko yang didapatkan

\section{Toleransi Risiko}

Toleransi risiko didefinisikan sebagai jumlah maksimum ketidakpastian bahwa seseorang bersedia menerima ketika membuat keputusan keuangan, mencapai ke hampir setiap bagian dari kehidupan ekonomi dan sosial [4]. Toleransi risiko merupakan kesiapan individu untuk ikut serta dalam perilaku investasi tertentu.

\section{Pengaruh Kepribadian terhadap Toleransi Risiko}

Kepribadian extraversion, conscientiousness dan openness to experience akan cenderung memilih instrumen investasi dengan tingkat risiko yang tinggi, sementara kepribadian dengan karakter agreeableness dan neuroticism akan cenderung memilih instrumen investasi rendah risiko [7].

Pengaruh Toleransi Risiko terhadap Keputusan Investasi Saham

Semakin tinggi tingkat toleransi risiko yang dimiliki oleh investor, maka akan semakin tinggi pula kecenderungan investor tersebut untuk berinvestasi pada aset berisiko [13]. Terdapat 3 perlakuan investor terhadap risiko investasi, yaitu risk averse, risk neutral, dan risk lover.

\section{METODOLOGI PENELITIAN}

\section{A. Data Penelitian}

Data yang digunakan dalam penelitian ini adalah data primer yang didapatakan dari pendistribusian kuesioner secara online maupun offline.

\section{B. Sampel Penelitian}

Purposive sampling digunakan untuk mengumpulkan sampel dengan kriteria, yaitu investor aset keuangan di Kota Surabaya dengan kriteria memiliki salah satu atau lebih dari satu produk aset keuangan. Sebanyak 124 kuesioner yang disebar, 95 diantaranya kembali, dan menyisakan 83 kuesioner yang layak.

Dalam penelitian ini akan dibagi menjadi 2 model uji, yaitu model I dengan menggunakan teknik analisis regresi linier berganda dan model II dengan menggunakan teknik analisis regresi linier sederhana. Model I dan II penelitian dapat dilihat pada Gambar 1.

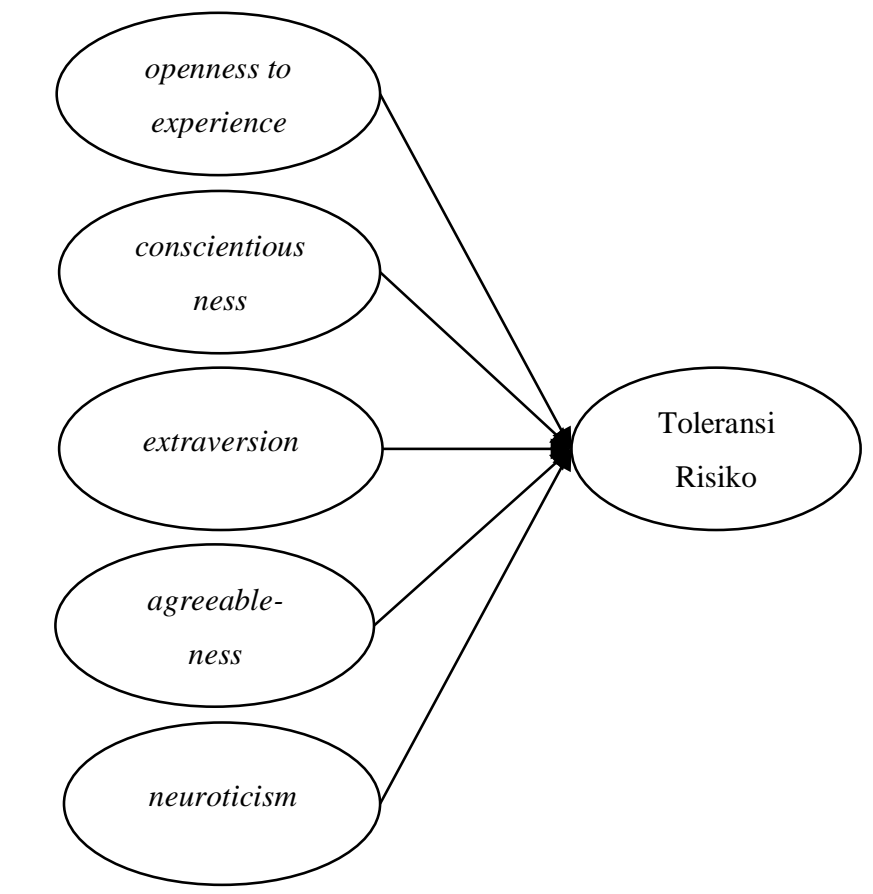

Gambar 1 Model I Penelitian

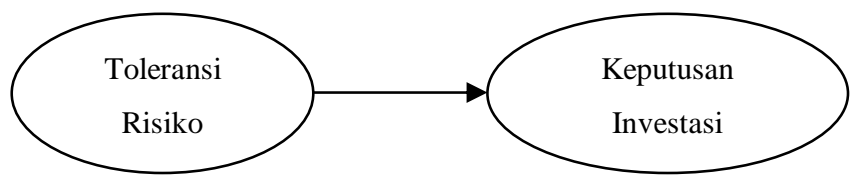

Gambar 2 Model II Penelitian

\section{Pengukuran Variabel}

Teknik pengukuran variabel yang digunakan dalam penelitian ini menggunakan skala Likert 1-5 untuk pengukuran lima variabel faktor kepribadian [14] dan toleransi risiko [7], sementara teknik pengukuran variabel keputusan investasi [13] yang digunakan adalah skala interval 1-100.

\section{HASIL DAN PEMBAHASAN}

\section{A. Profil Responden}

Hasil analisis deskriptif profil responden dapat dilihat pada Tabel 1.

Tabel 1

Profil Responden Penelitian

\begin{tabular}{lll}
\hline \hline Usia & & \\
\hline$<21$ tahun & 2 & $2 \%$ \\
$21-30$ tahun & 32 & $39 \%$ \\
$31-40$ tahun & 19 & $23 \%$
\end{tabular}




\begin{tabular}{|c|c|c|}
\hline $\begin{array}{l}41-50 \text { tahun } \\
51-60 \text { tahun } \\
>60 \text { tahun }\end{array}$ & $\begin{array}{l}12 \\
17 \\
1\end{array}$ & $\begin{array}{l}14 \% \\
20 \% \\
1 \%\end{array}$ \\
\hline \multicolumn{3}{|l|}{ Jenis Kelamin } \\
\hline $\begin{array}{l}\text { Perempuan } \\
\text { Laki-Laki }\end{array}$ & $\begin{array}{l}44 \\
39\end{array}$ & $\begin{array}{l}53 \% \\
47 \%\end{array}$ \\
\hline \multicolumn{3}{|l|}{ Pendapatan per tahun } \\
\hline$<50$ juta & 45 & $54 \%$ \\
\hline $\begin{array}{l}50 \text { juta }-<100 \text { juta } \\
100-<150 \text { juta }\end{array}$ & $\begin{array}{l}25 \\
8\end{array}$ & $\begin{array}{l}30 \% \\
10 \%\end{array}$ \\
\hline $\begin{array}{l}150 \text { juta }-<200 \text { juta } \\
200 \text { juta }-<250 \text { juta }\end{array}$ & $\begin{array}{l}2 \\
2\end{array}$ & $\begin{array}{l}2 \% \\
2 \%\end{array}$ \\
\hline$\geq 250$ juta & 1 & $1 \%$ \\
\hline \multicolumn{3}{|l|}{ Jenis Aset Keuangan } \\
\hline $\begin{array}{l}\text { Deposito } \\
\text { Saham } \\
\text { Reksadana }\end{array}$ & & $\begin{array}{l}55 \% \\
34 \% \\
18 \%\end{array}$ \\
\hline $\begin{array}{l}\text { Obligasi } \\
\text { Lainnya }\end{array}$ & & $\begin{array}{l}6 \% \\
20 \%\end{array}$ \\
\hline \multicolumn{3}{|l|}{ Total Investasi } \\
\hline $\begin{array}{l}<10 \text { juta } \\
10 \text { juta }-<50 \text { juta } \\
50 \text { juta }-<100 \text { juta } \\
>100 \text { juta }\end{array}$ & $\begin{array}{l}39 \\
21 \\
14 \\
9\end{array}$ & $\begin{array}{l}47 \% \\
25 \% \\
17 \% \\
11 \%\end{array}$ \\
\hline \multicolumn{3}{|l|}{ Waktu Kepemilikan } \\
\hline $\begin{array}{l}<1 \text { tahun } \\
1 \text { tahun }-<5 \text { tahun } \\
5 \text { tahun }-<10 \text { tahun } \\
>10 \text { tahun }\end{array}$ & $\begin{array}{l}21 \\
44 \\
13 \\
5\end{array}$ & $\begin{array}{l}25 \% \\
53 \% \\
16 \% \\
6 \%\end{array}$ \\
\hline
\end{tabular}

\section{B. Data Screening}

Data screening yang dilakukan dalam penelitian ini adalah pengecekan missing values dan pengecekan outliers. Berdasarkan hasil pengecekan, tidak ditemukan missing values atau seluruh pertanyaan kuesioner telah diisi seluruhnya oleh responden. Sementara berdasarkan hasil pengecekan outliers, diketahui terdapat 3 data univariate outliers dan 4 data multivariate outliers. Data outliers tersebut harus dihapus untuk memperoleh hasil uji yang lebih baik, dan menyisakan 76 data yang akan digunakan sebagai data untuk analisis selanjutnya.

\section{Validasi Data}

Validasi data yang dilakukan adalah dengan uji validitas dan uji reliabilitas. Berdasarkan hasil uji validitas diketahui 6 indikator yang tidak lolos uji validitas, sehingga harus dihapus. Indikator-indikator tersebut adalah indikator O6, O7, O10, E1, A4, dan N4. Sementara berdasarkan hasil uji reliabilitas diketahui bahwa pengukuran seluruh variabel dikatakan reliabel, karena nilai Cronbach alpha>0.5. Hasil nilai Cronbach alpha masing-masing variabel dapat dilihat pada Tabel 2.

Tabel 2 Hasil uji reliabilitas

\begin{tabular}{ccc}
\hline \hline No & Variabel & Alpha Cronbach's \\
\hline 1 & Openness to Experience & 0.797 \\
2 & Conscientiousness & 0.881 \\
3 & Extraversion & 0.838 \\
4 & Agreeableness & 0.808 \\
5 & Neuroticism & 0.863 \\
6 & Toleransi Risiko & 0.724 \\
\hline \hline
\end{tabular}

Penelitian ini menggunakan analisis regresi linier, sehingga model penelitian harus memenuhi kriteria BLUE (Best Liner Unbiased Estimator), yang mana dapat dicapai apabila model tersebut memenuhi uji asumsi klasik. Uji asumsi klasik tersebut terdiri dari uji normalitas, uji multikolinearitas, uji heterokedastisitas, dan uji autokorelasi.

\section{Uji Normalitas}

Berdasarkan hasil uji normalitas pada kedua model penelitian, diketahui bahwa model 1 penelitian memenuhi asumsi normalitas, sedangkan model 2 tidak memenuhi asumsi normalitas, sehingga harus dilakukan penanganan menggunakan trnasformasi data. Transformasi yang digunakan dalam penanganan masalah normalitas pada penelitian ini adalah akar kuadrat, mengacu pada hasil pengecekan Box-Cox Plot yang dilakukan.

\section{E. Uji Multikolinearitas}

Berdasarkan hasil uji multikolinearitas yang dilakukan pada model 1 penelitian, diketahui bahwa terdapat permasalahan multikolinearitas karena nilai signifikan yang muncul pada uji korelasi antar variabel independen, sehingga harus ditangani dengan menggunakan metode principal component analysis (PCA).

\section{F. Uji Heterokedastisitas}

Pemeriksaan heterokedastisitas dalam penelitian ini menggunakan metode uji Glejser. Uji ini dilakukan dengan meregresikan variabel independen penelitian dengan nilai absolut dari error variabel dependen. Syarat untuk tidak adanya heterokedastisitas dalam model tersebut dapat dilihat dari nilai $p$-value uji F yang dilakukan adalah $>0.05$. Berdasarkan hasil uji yang telah dilakukan pada kedua model penelitian, diketahui bahwa model 1 dan model 2 penelitian lolos uji heterokedastisitas.

\section{G. Uji Autokorelasi}

Berdasarkan hasil pemeriksaan autokorelasi pada model 1 dan 2 penelitian menggunakan Durbin Watson test, diketahui bahwa nilai $\mathrm{dw}$ model 1 adalah 0.564 . Nilai tersebut $<\mathrm{dL}$ $(1,4909)$ dan dU (1,7701), yang berarti model memiliki autokorelasi positif. Sehingga, diperlukan penanganan menggunakan Generalized Least Square (GLS). Sedangkan berdasarkan pengecekan autokorelasi pada model 2 dihasilkan bahwa model tidak memiliki autokorelasi karena $\mathrm{dw}=1,99>\mathrm{dL}$ $(1,6009)$ dan dU $(1,6541)$, serta < 4-dU $(2,35)$.

\section{H. Uji Regresi Linier}

Berdasarkan hasil uji regresi linier yang dilakukan pada model 1 dan model 2 penelitian, diketahui bahwa model 1 memiliki nilai $p$-value uji $\mathrm{F}$ adalah $0,122>0.05$, sehingga hal tersebut berarti bahwa variabel faktor kepribadian tidak dapat memprediksi toleransi risiko investor. Hasil uji regresi linier model 1 dan model 2 penelitian dapat dilihat pda Tabel 3. Hasil penelitian yang tidak berpengaruh ini dimungkinkan karena pemilik investasi aset keuangan di Surabaya cenderung rasional dalam pengambilan keputusan terkait imbal hasil dan risiko investasi yang dipilihnya. Kepribadian yang tidak berkorelasi dengan toleransi risiko ini terjadi karena tujuan dari investasi sendiri adalah untuk mendapatkan imbal hasil finansial atau 
mencapai kesejahteraan finansial di masa depan, yang mana hal tersebut akan mendorong individu cenderung untuk bertindak lebih rasional dalam pengambilan keputusannya dibandingkan dengan mengikuti cognitive bias seperti kepuasan diri semata [15] [16].

Tabel 3

Hasil Uji Regresi Model Penelitian

\begin{tabular}{ccc}
\hline Nilai & Model 1 & Model 2 \\
\hline$P$-value & 0.122 & 0.007 \\
$R$-square & $11.4 \%$ & $9.3 \%$ \\
\hline \hline
\end{tabular}

Sementara untuk model 2 penelitian, diketahui bahwa nilai $p$-value uji $\mathrm{F}$ adalah $0,007<0.05$, sehingga model penelitian dapat digunakan untuk memprediksi variabel dependen model 2 penelitian, dengan persamaan sebagai berikut:

$$
\begin{gathered}
\sqrt{y}=3,07+0,684 \text { Risk Tolerance } \\
\text { atau } \\
y=9,425+4,20 \text { Risk Tolerance }+0.468 \text { Risk Tolerance }{ }^{2}
\end{gathered}
$$

Berdasarkan hasil regresi linier pada model 2 tersebut, diketahui nilai $\beta$ dari variabel toleransi risiko adalah sebesar 0.684 untuk variabel dependennya adalah $\sqrt{y}_{\mathrm{y}}$, yang mana hal ini mengindikasikan bahwa semakin tinggi toleransi risiko yang dimiliki oleh individu, akan semakin besar preferensi investor untuk mengalokasikan aset investasi pada saham, begitupun sebaliknya. Hasil penelitian ini tentunya dapat digunakan oleh penasehat investasi dalam memprediksi preferensi investor dalam pengalokasian investasi saham dari total portofolio aset keuangan yang bersedia investor ambil. Informasi mengenai tingkat toleransi risiko investor ini dapat pensasehat investasi gali dari mini survei yang dilakukan kepada calon investor yang menggunakan jasanya untuk perencanaan investasi, yang mana semakin tinggi toleransi risiko yang dimiliki oleh investor, maka akan semakin tinggi pula preferensi investasi saham yang bersedia untuk investor ambil.

Dari hasil analisis pula diketahui bahwa nilai $\mathrm{R}$ square model ini adalah sebesar 9,3\%, yang artinya variabel toleransi risiko menggambarkan prediksi 9,3\% untuk keputusan investasi saham, dan sisanya dijelaskan oleh variabel lain yang ada di luar penelitian. Kecilnya $R$-square model ini bisa terjadi karena masih banyaknya variabel lain di luar penelitian yang mampu menjelaskan mengenai keputusan investasi saham, yang mana berdasarkan penelitian sebelumnya, variabel cognitive bias dan socially responsibility investment juga merupakan variabel yang berada pada dimensi keputusan keuangan [17].

\section{KESIMPULAN/RINGKASAN}

Berdasarkan analisis yang telah dilakukan, terdapat 2 (dua) simpulan yang dapat ditarik dari penelitian ini:

1. Diketahui bahwa investor aset keuangan perempuan di Surabaya mayoritas lebih cenderung memilih instrumen investasi berupa deposito perbankan, sementara investor aset keuangan laki-laki dengan karakteristik kepribadian extraversion dan agreeableness lebih cenderung memilih instrumen investasi pasar modal, seperti saham, reksadana, dan obligasi. Selain itu, mayoritas investor aset keuangan merupakan individu yang telah menikah dengan rentang usia 21-30 tahun dan berpendapatan $<50$ juta per tahunnya serta dengan waktu kepemilikan 1-5 tahun. Sementara invetor aset keuangan yang memiliki toleransi risiko tinggi adalah investor laki-laki dengan tingkat financial literacy terkait pasar modal yang tinggi.

2. Kepribadian (openness to experience, conscientiousness, extraversion, agreeableness, dan neuroticism) tidak memiliki pengaruh kepada toleransi risiko investor, karena investor aset keuangan yang cenderung rasional dalam pengambilan keputusannya.

3. Tingkat toleransi risiko memiliki pengaruh positif terhadap keputusan untuk berinvestasi saham, yang mana semakin tinggi tingkat toleransi risiko individu yang dimiliki, maka akan semakin tinggi pula preferensi investasi saham yang bersedia untuk investor ambil.

Berdasarkan hasil penelitian yang diperoleh, terdapat 2 (dua) saran yang dapat diberikan, yaitu:

1. Untuk penasehat investasi: kepribadian tidak berpengaruh terhadap toleransi risiko investasi, sehingga penasehat investasi tidak dapat menggunakan informasi mengenai kepribadian investor untuk memprediksi tingkat toleransi risiko investor, namun dapat menggunakan informasi mengenai tingkat toleransi risiko untuk memprediksikan preferensi investasi saham yang bersedia diambil oleh investor. Penasehat investasi dapat menggunakan mini survei untuk mengetahui tingkat toleransi investor dalam memprediksi preferensi keputusan investasi saham yang bersedia diambilnya.

2. Untuk penelitian selanjutnya: memperluas wilayah penelitian, seperti menggunakan responden penelitian yang tidak hanya di Kota Surabaya dan menggunakan variabel-variabel prediktor toleransi risiko yang lain tidak hanya kepribadian saja dan juga variabel prediktor keputusan investasi saham yang lain selain variabel toleransi risiko.

\section{DAFTAR PUSTAKA}

[1] BPS, "Laporan Perekonomian 2016," Badan Pusat Statistik, Jakarta, 2016.

[2] KPMG indonesia, "Investing in Indonesia 2015," KPMG indonesia, 2015.

[3] Z. Bodie, A. Kane and A. J. Marcus, Investments, 10th Edition, McGraw Hill, 2014.

[4] C. H. Chang, "The Impact of Behavioral Pitfalls on Investors' Decisions: The Disposition Effect in The Taiwanese Warrant Market," Social Behavior and Personality, pp. 617-634, 2008.

[5] Manulife Indonesia, "Manulife Investor Sentiment Index," February 2016. [Online]. Available: https://manulife-indonesia.com/. [Accessed 17 April 2016].

[6] J. E. Grable, "Financial Risk Tolerance and Additional Factors that Affect Risk Taking in Everyday Money Matters," Journal of Business and Psychology, 2000.

[7] C. Mayfield, G. Perdue and K. Wooten, "Investment Management and Personality Type," Financial Services Review 17, pp. 219-236, 2008.

[8] O. Pak and M. Mahmood, "Impact of personality on risk tolerance and investment decisions: A study on potential investors of Kazakhstan," International Journal of Commerce and Management, vol. 25, no. 4, pp. 370 - 384, 2013. 
[9] L. C. Crysel, B. S. Crosier and G. D. Webster, "The Dark Triad and risk behavior," Personality and Individual Differences 54, pp. 35-40, 2013.

[10] O. John and S. Srivastava, The Big-Five Trait Taxonomy: History, Measurement, and Theoretical Perspectives, New York: Guilford, 1991.

[11] O. P. John, R. W. Robins and L. A. Pervin, Handbook of Personality : Theory and Research. Third Edition, New York: The Gulford Press, 2008.

[12] H. J. Fabozzi and H. M. Markowitz, The Theory and Practice of Investment Management, Second Edition: Asset Allocation, Valuation, Portfolio Construction, and Strategies, New Jersey: John Wiley \& Sons, Inc. , 2011, pp. 99-116.

[13] G. Hariharan, K. S. Chapman and D. L. Domian, "Risk Tolerance and Asset Allocation for Investors Nearing Retirement," Financial Services Review 9, p. 159-170, 2000.

[14] D. Schmitt, J. Allik, R. R. McCrae and V. B. Martínez, "The Geographic Distribution of Big Five Personality Traits: Patterns and Profiles of Human Self-Description Across 56 Nations," Journal of Cross-Cultural Psychology, pp. 173-212, 2007.

[15] R. Hastie and R. M. Dawes, Rational Choice in An Uncertain World: The Psychology of Judgment and Decision Making, California: Sage Publications, Inc, 2010.

[16] N. Saxena and P. Puri, "Relationship between Risk Taking Behaviour, Personality and Sensation Seeking Tendencies among N.C.C cadets," IOSR Journal Of Humanities And Social Science, pp. 1-6, 2013.

[17] K. Joyce and N. K. Y. L, "The Influence of Personality Trait and Demographics on Financial Decision Making among Generation Y," Young Consumers, pp. 230-243, 2013. 